\section{Modern activist journalism}

Censored 2014: Fearless Speech in Fateful Times, by Mickey Huff and Andy Lee Roth with Project Censored. New York: Seven Stories Press, 2013, 431pp. ISBN 978-1-60980-484-7

$\mathrm{F}$ ROM its provocative title to its inclusion of contributions from observers like John Pilger, Censored 2014 provides no space for a counter narrative to its criticism of what it calls the corporate or establishment media. Heroes abound but they aren't The New York Times or CNN. Instead we're told it's Bradley Manning, Glen Greenwald or Iceland who deserve praise rather than censure. The project feels there are three main stories which are routinely and deliberately ignored by existing media outlets: climate change, economic inequality and conflicts launched in the name of Empire. This last conclusion is one that goes uncontested even when chapters are devoted to how independent journalists are disparaged as conspiracy theorists by their mainstream rivals if they call attention to false flag terrorism, or demand full investigations into $9 / 11$.

Nonetheless, readers may find references to the Trans-Pacific Partnership timely - though lacking in regionally specific detail. Most of the focus is on the American media environment

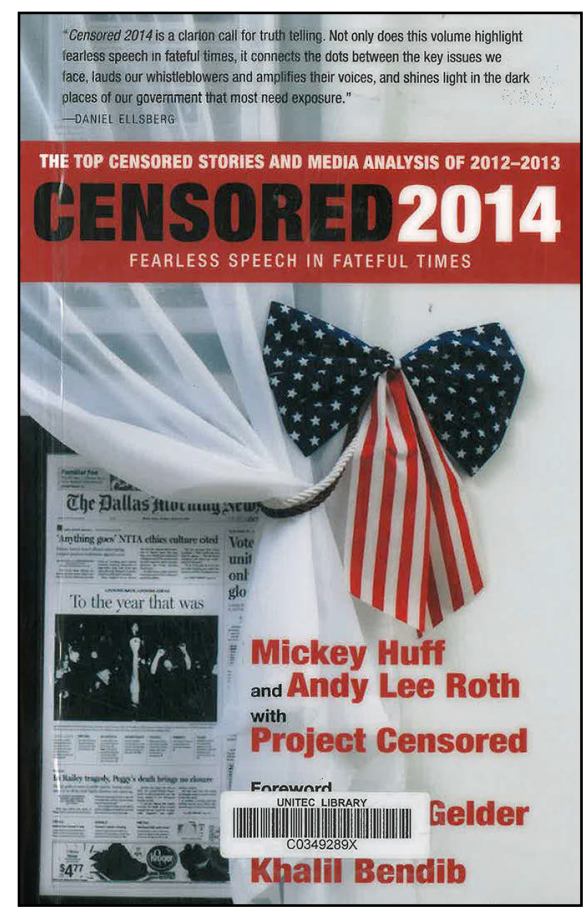

and contains views strongly opposed to neoliberalism as well as historic and contemporary US foreign policy. It is a framework in which out of context Postman quotes and Chomskyan perspectives are de rigueur. It is also one which could benefit from the Foucaultian ethos it purports to espousethe opportunity to speak critically and without fear; and to continue the discourse over the merits of modern activist journalism and its alternatives with fewer polemics.-Steve Ellmers is a Unitec lecturer. 